\title{
DUDI MAIA ROSA
}

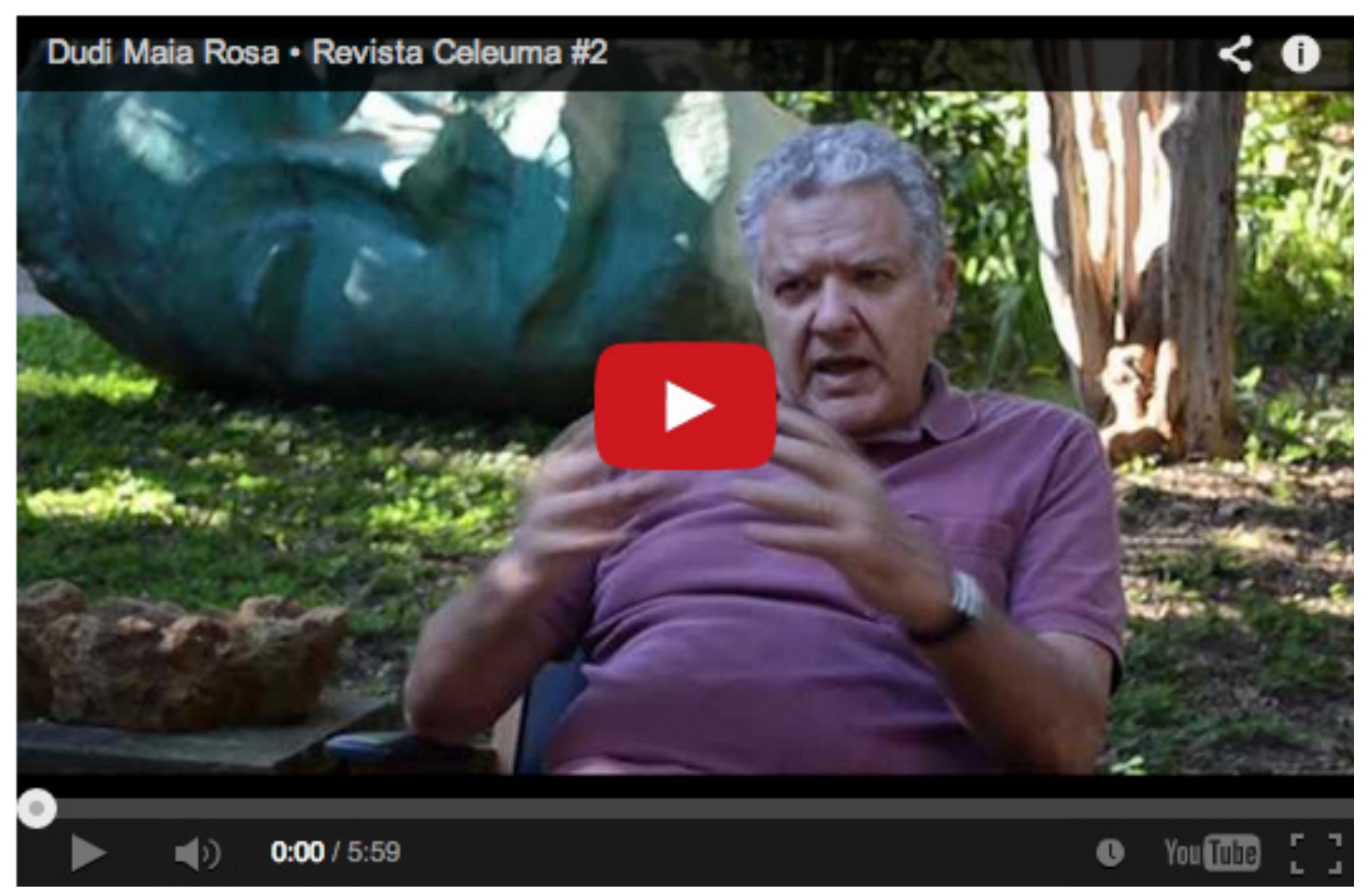

